\section{Развитие национальной системы платежных карт в России в условиях экономических санкций}

Д.А. КОчеРгин, доктор экономических наук. E-mail: kda2001@gmail.ru А.И. ЯнгИРОВА, Санкт-Петербургский государственный университет, Санкт-Петербург. E-mail: alsu-rf@mail.ru

Цель статьи - исследование основных этапов формирования национальной системы платежных карт (НСПК) в России в условиях экономических санкций. Авторами проанализированы ключевые факторы, характеризующие современное развитие НСПК, сделаны выводы о необходимости совершенствовать инфраструктуру приема и расчетов, активнее внедрять экономические стимулы для участников платежной системы. В долгосрочной перспективе российская НСПК сможет успешно конкурировать с международными платежными системами на российском рынке только в том случае, если будет способна внедрять инновации в сфере приема и обработки платежей, а также предлагать ценовые и функциональные конкурентные преимущества по своим продуктам.

Результаты могут быть использованы экономистами-исследователями, кредитными институтами и национальными регулирующими органами для совершенствования развития национальной системы платежных карт, повышения ее эффективности и стимулирования роста безналичных платежей в стране.

Ключевые слова: платежная система, национальная система платежных карт, безналичные платежные инструменты, платежная карта «Мир»

Создание в 2014 г. российской национальной системы платежных карт было продиктовано не столько экономическими причинами (стремлением снизить издержки, повысить скорость и безопасность проведения платежей, улучшить платежную инфраструктуру в стране), сколько политическими факторами, прежде всего, введением США и другими западными странами экономических санкций в отношении России, в результате которых резко возросли внутристрановые платежные риски.

Одной из основных задач, которые призвана решить российская национальная система платежных карт, является обеспечение суверенитета платежного пространства на территории страны.

Это предполагает установление единого набора правил и процедур для всех участников платежной инфраструктуры, а также унификацию системы управления рисками внутристрановых расчетов. Главная его цель - повышение безопасности и эффективности проведения платежей, снижение платежнорасчетных рисков, повышение стабильности функционирования национальной платежной системы. Обязательными элементами национального платежного пространства являются национальная система платежных карт и единый расчетный центр по переводу денежных средств с использованием всех типов банковских платежных карт (в России эту роль выполняет ЦБ РФ).

Проект создания национальной системы платежных карт в России не уникален. Заслуживает внимания опыт ряда западных и восточноазиатских стран (Канада-платежная ассоциация Interac, Франция - система Cartes Bancaires, Дания - Dankort, Япония - JCB, Китай - UnionPay, Индия - RuPay, Вьетнам - BanknetVN и др.). Мы проанализируем российскую национальную систему платежных карт, чтобы выявить характерные особенности ее формирования и сделать выводы относительно перспектив ее развития.

\section{Основные характеристики российской НСПК}

Российская национальная система платежных карт была создана в июле 2014 г. в форме АО «НСПК». На сегодняшний день владельцем 100\% ее акций является Банк России.

Первый этап развития НСПК в России заключался в переносе процессинга по всем транзакциям с использованием карт международных платежных систем ${ }^{1}$ на территорию страны. В конце первого квартала 2015 г. в Россию была переведена обработка внутристрановых операций по картам VISA и MasterCard (доля которых составляла около 99\% от выпущенных в России карт международных систем²). Процессинг по картам остальных международных систем, присутствовавших в России (JCB, American Express и UnionPay), был локализован в 2016 г. Это позволило исключить потенциальное влияние внешних факторов на функционирование национального платежного пространства.

${ }^{1}$ В соответствии с Реестром операторов платежных систем, приведенном на официальном сайте ЦБ РФ, на территории России в 2017 г. функционировало пять международных карточных платежных систем: VISA, MasterCard, JCB, American Express, UnionPay.

${ }^{2}$ По данным с «круглого стола» платежной системы «Мир» на Форуме инновационных финансовых технологий Finopolis 2017, перевод процессинга в российскую НСПК привел к увеличению расходов VISA в годовом выражении на 70 млн долл., в MasterCard на 50 млн долл. без учета стоимости обработки транзакций через российскую НСПК. При этом в 2016 г. выручка российской НСПК за обработку транзакций международных платежных систем составила 6,2 млрд руб. 
Второй этап развития НСПК в России заключался в разработке и выпуске национальной платежной карты (по результатам всероссийского конкурса карта и платежная система в целом получили название «Мир»). Эмиссия карт платежной системы «Мир» (ПС «Мир») началась 15 декабря 2015 г. Первыми национальные платежные карты выпустили Газпромбанк, МДМ Банк, Московский Индустриальный банк, РНКБ Банк, Банк «РОССИЯ», Связь-Банк и СМП Банк. В свою очередь АО «НСПК» стало оператором ПС «Мир».

С 01.07.2017 г. был начат выпуск платежных карт «Мир» для получателей бюджетных выплат при их обращении за открытием нового карт-счета. Тогда же все российские банки начали прием карт «Мир» в своих банкоматных и эквайринговых сетях. С 01.10.2017 г. их обязаны принимать все торгово-сервисные предприятия с годовым оборотом более 40 млн руб. ${ }^{3}$ Предполагается, что в 2018 г. данное требование распространится на все торговые точки в российском сегменте сети Интернет.

С 01.07.2018 г. будет начат выпуск платежных карт «Мир» для действующих получателей бюджетных выплат на счет, к которому выпущены карты других платежных систем. До 01.07.2020 г. будет осуществлен выпуск платежных карт ПС «Мир» для пенсионеров, имеющих карты других платежных систем, в рамках их планового перевыпуска ${ }^{4}$.

Третий этап предусматривает мероприятия по насыщению продуктовой линейки НСПК актуальными платежными продуктами и сервисами, их продвижению и развитию на территории России, а также за ее пределами.

Отметим, что преимущественный выпуск карт ПС «Мир» работникам бюджетных предприятий, а также пенсионерам и студентам несет определенные риски для будущего развития НСПК. Они обусловлены, во-первых, низкими доходами данных слоев населения и, как следствие, пределом в обороте средств по таким картам. Во-вторых, работники бюджетных предприятий, а также

3 Пункт 1 статьи 16.1 федерального закона от 07.02.1992 № 2300-1 «О защите прав потребителей» (ред. от 18.04.2018) // СПС Консультант Плюс.

${ }^{4}$ Пункт 5.3 статьи 30.5 федерального закона от 27.06.2011 № 161-Ф3 «О национальной платежной системе» (с изм. и доп. от 01.05.2017, вступ. в силу с 01.10 .2017$) / /$ СПС Консультант Плюс. пенсионеры в среднем значительно реже пользуются картами для платежных целей, нежели другие слои населения России.

Как показано на рисунке 1, на начало января 2017 г. было выпущено всего около 1,62 млн платежных карт ПС «Мир», а на начало января 2018 г. - уже 28,67 млн (рост более чем в 17 раз). Однако, поскольку к январю 2018 г. на территории РФ было выпущено в общей сложности более 270 млн платежных карт (кредитных и дебетовых $)^{5}$, доля национального платежного инструмента составила всего $10,58 \%$ (рис. 2).

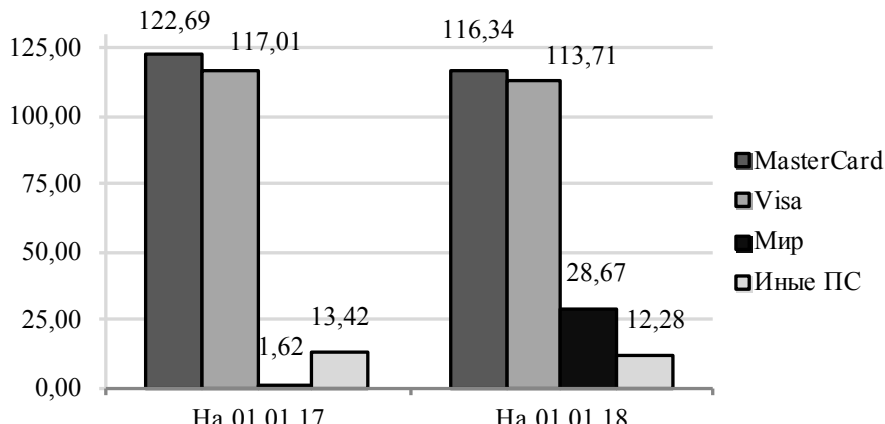

Источник рис. 1-3: Форма отчетности 0409250 «Сведения об операциях с использованием платежных карт и инфраструктуре, предназначенной для совершения с использованием и без использования платежных карт операций выдачи (приема) наличных денежных средств и платежей за товары (работы, услуги)", направляемой кредитными организациями в Банк России, по состоянию на 01.01.2018г.

Рис. 1. Количество карт в России по типам платежных систем в 2016-2017 гг., млрд ед.

Как видно на рисунке 3, рынок платежных карт в регионах России развивался неравномерно. На начало января 2017 г. основная часть эмитированных карт ПС «Мир» приходилась на Южный федеральный округ. Это объясняется неразвитостью инфраструктуры по приему карт других платежных систем на территории Республики Крым и г. Севастополь. Однако к январю 2018 г. распределение карт ПС «Мир» приобрело более равномерный характер с преобладанием в наиболее густонаселенных регионах России.

${ }_{5}^{5}$ Основные показатели развития национальной платежной системы // Официальный сайт ЦБ РФ [Эл. pecypc]. URL: https://www.cbr.ru/statistics/p sys/print. aspx?file=sheet001.htm\&pid=psrf\&sid=ITM 30245 (дата обращения: 01.02.2017). 


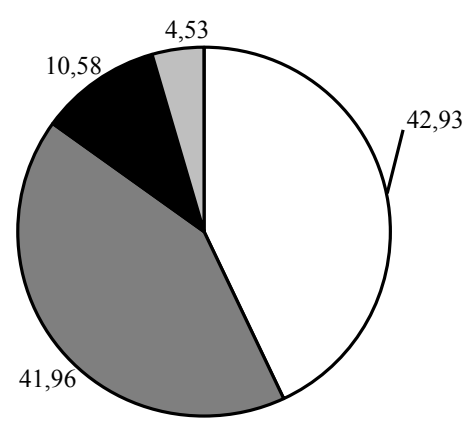

口MasterCard

口Visa

口иир

口Иные ПС

Рис. 2. Доля карт в России по типам платежных систем на $01.01 .2018, \%$

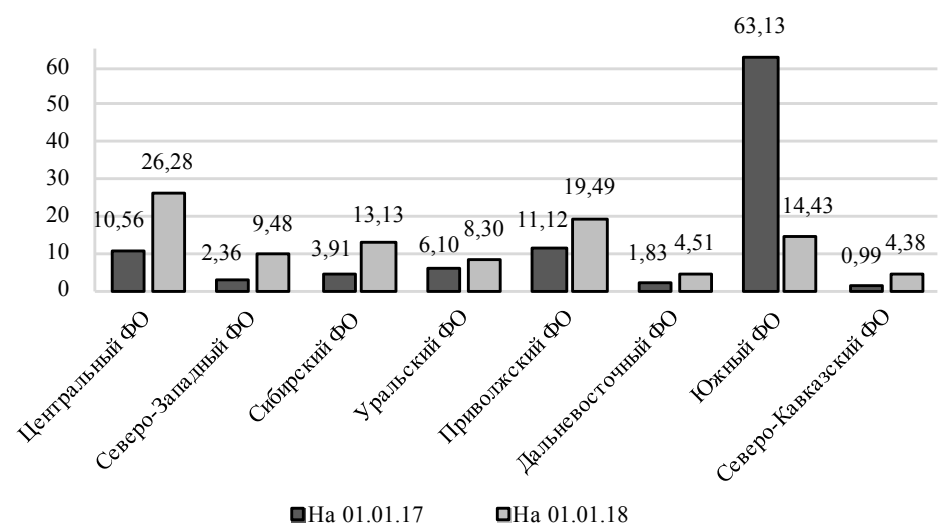

Рис. 3. Региональное распределение эмитированных карт ПС «Мир» в 2016-2017 гг.,\%

В преддверии 2018 г. произошел большой скачок в части эмиссии национального платежного инструмента, поэтому развитие ПС «Мир» в данный и последующие периоды представляет особый интерес для экономистов-исследователей. Так, в 2017 г. операции по картам ПС «Мир» заняли значительное место в общей доле осуществленных операций - 7,59\% по сумме и 7,4\% по количеству, в то время как аналогичные показатели в 2016 г. составляли всего 0, 3\% и 0,16\% (данные за IV квартал).

\section{Основные параметры и факторы развития российской НСПК}

Развитие национальной системы платежных карт в России характеризуется следующими особенностями:

1) создание НСПК продиктовано необходимостью защитьл национального платежного пространства. С этим связаны предельно короткие сроки эмиссии платежных карт, объединения банков-эмитентов и банков-эквайреров в единую платежно-расчетную сеть, создание инфраструктуры по приему карт на национальном уровне;

2) для развития НСПК используются меры государственной поддержки на законодательном и административном уровнях. К их числу относятся введение требований по эмиссии карт ПС «Мир» российскими банками, а также по приему национальных карт в существующих эквайринговых и банкоматных сетях, по переводу заработной платы и различных социальных выплат бюджетным группам населения на национальные карты и др.;

3) развитие НСПК, несмотря на заявленный приоритет защиты национального платежного пространства, не ограничивается национальными границุами. ПС «Мир» ставит амбициозный план по выводу своих карточных продуктов на зарубежные рынки. Срок, отведенный на зарубежную экспансию карт «Мир», составляет около пяти лет - 2015-2019 гг. ${ }^{6}$

Наш анализ формирования и развития российской НСПК был проведен по нескольким факторам.

1. Предпосылки создания. Попытки создания национальной карточной платежной системы предпринимались неоднократно на протяжении 1993-2014 гг. Их инициаторами и участниками выступали коммерческие банки. Примерами могут служить система UnionCard (основана в 1993 г,, объединила более 300 банков), «Золотая Корона» (основана в 1994 г., объединила более 550 банков), а также проекты ПАО Сбербанк - «Сберкарт» и «ПРО100» (1994-2016 гг.) и др. Ни один из этих проектов не дорос до общенационального масштаба из-за ограниченности средств на создание инфраструктуры и отсутствия государственной поддержки.

${ }^{6}$ Например, японской платежной системе JСВ, основанной в 1961 г., потребовалось 20 лет для вывода своих карт на международный уровень. 
Напротив, НСПК создавалась при отсутствии явно выраженных экономических стимулов, но при этом пользовалась беспрецедентной государственной поддержкой, что было вызвано прежде всего приоритетами финансовой безопасности государства в условиях введения экономических санкций в отношении России.

Напомним, в марте 2014 г., после присоединения Россией Республики Крым, США и их союзники впервые ввели экономические санкции против отдельных российских физических лиц и организаций. Так, 21 марта 2014 г. международные платежные системы VISA и MasterCard приостановили доступ к своим платежным сервисам для банков, входящих в санкционный список (АБ «Россия», Собинбанк, СМП Банк и Инвесткапиталбанк). Далее 19 декабря 2014 г. в рамках нового пакета санкций было объявлено о прекращении выпуска и обслуживания карт VISA на территории Республики Крым и г. Севастополь, а с 26 декабря 2014 г. - и системы MasterCard.

В результате безопасность российского платежного пространства была поставлена под угрозу, несколько десятков тысяч человек оказались отрезаны от сервисов и инфраструктуры международных платежных систем. Возможным последствием введения экономических санкций против России долгое время считался также риск отключения российских банков от системы международных расчетов SWIFT ${ }^{7}$, которая играет важную роль в построении платежно-расчетных отношений на территории РФ [Портанский, 2014].

2. Цели и задачи развития. Как отмечалось, на момент создания НСПК более $90 \%$ российского рынка карточных платежей (как в количественном, так и стоимостном разрезе) приходились на карты МПС. Реализация проекта НСПК происходила в режиме экономических санкций при низких темпах экономического роста в стране (прирост ВВП-менее 1\%). Эти важные экономические детерминанты сказались на определении цели и задач развития НСПК.

Первоочередная цель заключалась в обеспечении бесперебойности операций по платежным картам, замыкании внутристрановых транзакций на одной площадке и снижении зависимости от международных платежных систем. Данная цель была выполнена путем

Society for Worldwide Interbank Financial Telecommunications - Общество всемирных межбанковских телекоммуникаций. создания в марте 2015 г. операционного и платежно-клирингового центра НСПК, который обеспечил перевод всех внутренних и внешних транзакций на территорию России.

Кроме того, согласно «Стратегии развития национальной системы платежных карт», целями развития НСПК являются обеспечение доступного оказания услуг по переводу денежных средств в Российской Федерации с использованием национальных и международных платежных инструментов в условиях конкуренции с существующими платежными системами, повышение доверия пользователей к безналичным расчетам ${ }^{8}$.

Для достижения указанных целей необходимо решение следующих основных задач: организация взаимодействия между участниками финансового рынка по осуществлению ими денежных переводов с использованием международных платежных карт и национальных платежных инструментов, обеспечение эмиссии национальных платежных инструментов, а также продвижение продуктов и сервисов НСПК на международном рынке.

Реализация данных задач осуществляется путем создания широкой инфраструктуры приема карт ПС «Мир», вступления основных игроков банковского сектора в платежную систему, заключения соглашений по совместному выпуску национального платежного инструмента со странами - участницами ЕврАзЭС, международными платежными системами.

Особенность российского платежного рынка состоит в том, что государство всегда направляло основные ресурсы на развитие платежной инфраструктуры лишь в небольшом числе крупнейших городов. Для максимального охвата населения страны сервисами и услугами ПС «Мир» эти карты были задействованы в рамках самого широкого спектра зарплатных проектов (поначалу - в бюджетных, затем - и частных предприятиях и организациях).

3. Внутренняя структура. Центральным эмитентом национальной системы является АО «НСПК», деятельность которого контролируется Центральным банком. На данный момент Банк России - единственный акционер общества, хотя законом допускается наличие других, включая Внешэкономбанк, иностранные и международные финансовые организации, выступающих

${ }^{8}$ Стратегия развития национальной системы платежных карт, утверждена решением Наблюдательного совета $\mathrm{AO}$ «НСПК» 09.02.2015. С. 2 [Эл. ресурс]. URL: http://www. nspk.ru/about/investor-relations/strategy/ (дата обращения: 28.11.2017). 
в качестве индивидуальных участников НСПК. У Банка России должны оставаться не менее $50 \%$ плюс одна голосующая акция.

Расчетным центром ${ }^{9}$ НСПК также является Банк России. Ранее расчетным центром в России для MasterCard выступал ПАО Сбербанк, а для VISA - Банк ВТБ (ПАО). Очевидно, что после перевода расчетов в ЦБ РФ прибыль ПАО Сбербанк и Банк ВТБ (ПАО) от карточных операций несколько сократилась. Однако, будучи крупнейшими клиентами ПС «Мир», они теперь аккумулируют немалые денежные средства на счетах оператора и зарабатывают на выпуске и обслуживании карт.

На начало апреля 2018 г. в ПС «Мир» вступили более $67 \%$ действующих на территории Российской Федерации банков ${ }^{10}$.

4. Международное сотрудничество. Несмотря на наличие очевидного конфликта между НСПК и международными платежными системами, российская система платежных карт заинтересована в международном сотрудничестве, поскольку лишь оно позволяет выйти на международные платежные рынки. На данный момент планируется выход платежной карты ПС «Мир» за пределы России путем создания единого платежного пространства со странами - участницами Евразийского экономического союза, а также за счет сотрудничества с международными системами MasterCard, JCB, AmEx, UnionPay в целях запуска кобейджинговых карт. Так, в декабре 2015 г. были выпущены первые кобейджинговые карты Мир-Maestro, в августе 2016 г. Мир-ЈСВ, а в июле 2017 г. - Мир-UnionPay.

Такие партнерские проекты позволяют распространять продукты и сервисы ПС «Мир» за пределами России и преодолевать неполноту функционала национальных платежных карт на начальном этапе. Однако подобное сотрудничество касается лишь ограниченных сфер взаимодействия и не обеспечивает платежный суверенитет ввиду возможного нарушения работоспособности карт при их использовании на территории других стран и создание уникальной платежной системы, способной конкурировать с мировыми.

\footnotetext{
Согласно Глоссарию терминов, используемых в платежных и расчетных системах, утвержденному Комитетом по платежным и расчетным системам, расчетным банком может являться ЦБ либо частный банк, осуществляющий денежные расчеты (Committee on Payments and Market Infrastructures. BIS, 2016. 2017. October. (Updated). P. 16.).

${ }^{10}$ Участники платежной системы «Мир». Официальный сайт $\mathrm{AO}$ «НСПК» [Эл.ресурс]. URL: http://www.nspk.ru/cards-mir/uchastniki-ps-mir/ (дата обращения: 10.03.2018).
}

5. Региональные проекты. Одним из принципиальных отличий российской НСПК от международных платежных систем и, по нашему мнению, важным потенциальным конкурентным преимуществом является ее нацеленность на развитие региональных совместных проектов. На большинстве развитых и развивающихся рынков деятельность международных платежных систем ориентирована преимущественно на совмещение платежной карты и дисконт-программ различных торговых организаций.

Еще в 1998 г. в докладе Европейского центрального банка ${ }^{11}$ была предложена идея создания многофункциональной карты, представляющей собой инструмент, который, в дополнение к функции хранения стоимости, может включать другие платежные возможности, например, функцию дебетовой или кредитной карты и/или неплатежные функции. Попытка реализации данной идеи была осуществлена в области здравоохранения. Так, медицинские учреждения по всему миру начали разрабатывать проекты по совмещению в одном карточном продукте платежной функции и сведения о состоянии здоровья держателя этой карты, предназначенных для использования при оказании скорой и неотложной помощи. Однако большинство проектов, даже наиболее крупные и многообещающие, такие как европейская карта CARDLINK, немецкая MPK и французская VITALE-2, оказались свернуты по причине дороговизны выпуска карты, отсутствия должной инфраструктуры и недооценки сложностей внедрения подобных карточных систем, из-за которых они не были восприняты ни врачами, ни пациентами [Быстров, 2005].

В настоящее время, сотрудничая с правительствами субъектов РФ, крупнейшими банками и частными компаниями, НСПК реализует наделение платежных карт ПС «Мир» дополнительным функционалом, что позволит повысить привлекательность карт и стимулировать более активнее их использование на территории страны. Например, у НСПК уже заключены ряд соглашений с правительствами некоторых регионов по выпуску многофункциональной смарт-карты на базе ПС «Мир».

В таблице 1 представлены основные региональные проекты, реализуемые российской НСПК в сотрудничестве с региональными банками и частными компаниями.

${ }^{11}$ Report on electronic money //European Central Bank. 1998. August. P. 40. 
Таблица 1. Основные региональные проекты, реализуемые Нспк ${ }^{12}$

\begin{tabular}{|c|c|c|c|}
\hline Проект & $\begin{array}{c}\text { Карточный инстру- } \\
\text { мент, используемый } \\
\text { в проекте }\end{array}$ & $\begin{array}{l}\text { Сроки подписания и } \\
\text { реализации проекта }\end{array}$ & Участники \\
\hline $\begin{array}{l}\text { Социальная } \\
\text { карта москвича }\end{array}$ & \multirow{4}{*}{$\begin{array}{l}\text { Многофункциональная } \\
\text { персонализированная } \\
\text { смарт-карта на базе пла- } \\
\text { тежной карты ПС «Мир», } \\
\text { которая будет совмещать } \\
\text { в себе следующие } \\
\text { приложения: } \\
\text { - платежное; } \\
\text { - идентификационное; } \\
\text { - электронная подпись; } \\
\text { - социальные услуги } \\
\text { (хранение информации } \\
\text { о полисе ОМС, СНилС } \\
\text { и др.; } \\
\text { - транспортное }\end{array}$} & Подписание меморандума & $\begin{array}{l}\text { Центральный банк } \\
\text { Российской Федерации } \\
\text { и Правительство Москвы }\end{array}$ \\
\hline $\begin{array}{l}\text { Единая карта } \\
\text { петербуржца }\end{array}$ & & $\begin{array}{l}\text { Подписание меморандума } \\
\text { на XXV МФК } \\
30.06 .2016\end{array}$ & $\begin{array}{l}\text { Центральный банк } \\
\text { Российской Федерации } \\
\text { и Правительство Санкт- } \\
\text { Петербурга }\end{array}$ \\
\hline $\begin{array}{l}\text { Карта жителя } \\
\text { Ростовской } \\
\text { области }\end{array}$ & & $\begin{array}{l}\text { Подписание соглашения } \\
17.06 .2016 \text { г. }\end{array}$ & $\begin{array}{l}\text { АО «НСПК», Правитель- } \\
\text { ство Ростовской области, } \\
\text { Банк «Центр-инвест» }\end{array}$ \\
\hline $\begin{array}{l}\text { Единая } \\
\text { социальная } \\
\text { электронная } \\
\text { карта } \\
\text { (Республика } \\
\text { Мордовия) }\end{array}$ & & $\begin{array}{l}\text { Подписание соглашения } \\
\text { 06.07.2016 г. }\end{array}$ & $\begin{array}{l}\text { АО «НСПК», АККСБ «КС } \\
\text { БАНК», Республика } \\
\text { Мордовия }\end{array}$ \\
\hline $\begin{array}{l}\text { ЕКАРТА } \\
\text { (Екатеринбург) }\end{array}$ & $\begin{array}{l}\text { Платежная карта ПС } \\
\text { «Мир» с региональным } \\
\text { транспортным прило- } \\
\text { жением }\end{array}$ & $\begin{array}{l}\text { Международная выставка } \\
\text { «Иннопром-2016» } \\
11.07 .2016 \text { г. }\end{array}$ & $\begin{array}{l}\text { АО «НСПК», ГПБ (АО), } \\
\text { администрация Екате- } \\
\text { ринбурга }\end{array}$ \\
\hline $\begin{array}{l}\text { Платежная } \\
\text { карта жителя } \\
\text { республики } \\
\text { (Карачаево- } \\
\text { Черкесская } \\
\text { Республика) }\end{array}$ & $\begin{array}{l}\text { Многофункциональная } \\
\text { персонализированная } \\
\text { смарт-карта на базе пла- }\end{array}$ & $\begin{array}{l}\text { Подписание соглашения } \\
\text { на XV Международном } \\
\text { Инвестиционном форуме } \\
30.09 .2016\end{array}$ & $\begin{array}{l}\text { АО «НСПК», ПАО «Связь- } \\
\text { Банк», Карачаево-Чер- } \\
\text { кесская Республика }\end{array}$ \\
\hline $\begin{array}{l}\text { Карта жителя } \\
\text { Республики } \\
\text { Татарстан }\end{array}$ & $\begin{array}{l}\text { которая будет совмещать } \\
\text { в себе следующие } \\
\text { приложения: } \\
\text { - платежное; }\end{array}$ & $\begin{array}{l}\text { Подписание мемо- } \\
\text { рандума на Форуме } \\
\text { FINOPOLIS-2016 } \\
13.10 .2016 \text { г. }\end{array}$ & $\begin{array}{l}\text { Центральный банк Рос- } \\
\text { сийской Федерации, } \\
\text { Правительство } \\
\text { Республики Татарстан }\end{array}$ \\
\hline $\begin{array}{l}\text { Карта жителя } \\
\text { Республики } \\
\text { Башкортостан }\end{array}$ & $\begin{array}{l}\text { - идентификационное; } \\
\text { - электронная подпись; } \\
\text { - социальные услуги } \\
\text { (хранение информащии }\end{array}$ & $\begin{array}{l}\text { Подписание соглашения } \\
24.11 .2016 \text { г. }\end{array}$ & $\begin{array}{l}\text { АО «НСПК», Прави- } \\
\text { тельство Республики } \\
\text { Башкортостан, ПАО } \\
\text { «Банк УРАЛСИБ» }\end{array}$ \\
\hline $\begin{array}{l}\text { Карта жителя } \\
\text { Нижегородской } \\
\text { области }\end{array}$ & $\begin{array}{l}\text { о полисе ОМС, СНИЛС } \\
\text { и т.п.); } \\
\text { - транспортное }\end{array}$ & $\begin{array}{l}\text { Подписание соглашения } \\
\text { на X Международном } \\
\text { форуме инновационных } \\
\text { технологий «ТTFORUM2020/ } \\
\text { Цифровой мир» } \\
12.04 .2017 \text { г. }\end{array}$ & $\begin{array}{l}\text { АО «НСПК», правитель- } \\
\text { ство Нижегородской } \\
\text { области }\end{array}$ \\
\hline
\end{tabular}

${ }^{12}$ По материалам «круглого стола» платежной системы «Мир» на Форуме инновационных финансовых технологий Finopolis 2017 [Эл. pecypc]. URL: http://www.nspk.ru/about/press/ news_project/karty-mir-skoro-mozhno-budet-zagruzit-v-smartfon/?sphrase_id=25234 (дата обращения: 28.11.2017), а также официального сайта платежной системы «Мир» [Эл. pecypc]. URL: http://www.mironline.ru (дата обращения: 10.04.2018).

\begin{tabular}{|l|l|l|l|}
\hline \multicolumn{1}{|c|}{ Проект } & $\begin{array}{l}\text { Карточный инстру- } \\
\text { мент, используемый } \\
\text { в проекте }\end{array}$ & $\begin{array}{l}\text { Сроки подписания и } \\
\text { реализации проекта }\end{array}$ & \multicolumn{1}{c|}{ Участники } \\
\hline $\begin{array}{l}\text { Карта для } \\
\text { учащихся } \\
\text { высших учебных } \\
\text { заведений }\end{array}$ & $\begin{array}{l}\text { Совмещение платежного } \\
\text { и идентификационного } \\
\text { функционала, ключа } \\
\text { к инфраструктуре универ- } \\
\text { ситета и транспортного } \\
\text { приложения }\end{array}$ & $\begin{array}{l}\text { Массовый выпуск с начала } \\
2018 \text { г. }\end{array}$ & $\begin{array}{l}\text { АО «НСПК», кредитные } \\
\text { организации и высшие } \\
\text { учебные заведения. } \\
\text { Например, уже реали- } \\
\text { зованы карты учащихся } \\
\text { в МГСУ и Юфу }\end{array}$ \\
\hline
\end{tabular}

Таким образом, многофункциональная карта на базе ПС «Мир» может соединить в себе удобство пользования финансовыми и нефинансовыми инструментами, адресную социальную поддержку и прозрачность расходования бюджетных средств. Важно, что названные и иные приложения могут функционировать независимо друг от друга, что обеспечивает широкий спектр возможностей для их разработчиков и пользователей.

6. Потенциал развития и источники финансирования. При учреждении АО «НСПК» Банк России внес 0,5 млрд руб. в его уставный капитал. Согласно уставу АО «НСПК», общество вправе выпустить акции на 4 млрд руб. в дополнение к вложенной сумме, к чему оно и прибегло в 2015 г., после чего уставный капитал АО «НСПК» составил 4,3 млрд руб.

Для сравнения: финансирование проекта создания UnionPay в размере более 1,65 млрд юаней (240 млн долл. США) [Царенко, 2014] осуществлялось в рамках кредитной линии Всемирного банка, состоящего из двух взаимосвязанных подразделений: Международного банка реконструкции и развития (МБРР) и Международной ассоциации развития (МАР). Также для реализации проекта UnionPay потребовалась поддержка центральных банков США, Великобритании, Японии, Германии и Швейцарии.

Очевидно, что расширение инфраструктуры, разработка и продвижение платежных продуктов и сервисов требуют больших финансовых вложений. Однако, по данным годовой финансовой отчетности $\mathrm{AO}$ «НСПК», уже начиная с 2016 г. все операционные и инвестиционные расходы осуществлялись обществом исключительно за счет собственных средств. Деятельность АО «НСПК» показывает стабильный рост: по итогам 2017 г. чистая прибыль составила 3,3 млрд руб., что на 27,5\% превышает аналогичный показатель за 2016 г., уровень рентабельности $-36,7 \%$. Существенное влияние на результаты прибыли 
оказала выручка компании, составившая в 2017 г. 7,9 млрд руб. и увеличившаяся за год на 1,7 млрд руб. ${ }^{13}$

Для поддержания финансовых результатов и дальнейшего расширения деятельности АО «НСПК» необходимо привлекать максимальное количество участников в лице кредитных организаций, иностранных банков и международных финансовых организаций, которые являются посредниками между операторами и конечными потребителями карточных продуктов.

Ввиду того, что главная роль в организации раскрытия банкоматной и эквайринговой сети лежит на кредитных организациях, а на торгово-сервисные предприятия ложится основное бремя по оплате комиссии за обслуживание операций по оплате товаров и услуг по карте, одним из ключевых стимулов для привлечения большего числа участников в ПС «Мир» являются конкурентоспособные тарифы. В таблице 2 представлены результаты сравнительного анализа различных направлений тарифной политики международных платежных систем Visa и MasterCard и карты ПС «Мир».

Как можно видеть из таблицы, АО «НСПК» предлагает довольно привлекательные условия для кредитных организаций, желающих осуществлять прием платежной карты ПС «Мир». Банк России в настоящее время не раскрывает информацию по состоянию платежной инфраструктуры ПС «Мир». Однако, по данным АО «НСПК», на начало 2018 г. не все электронные терминалы в торгово-сервисных предприятиях были переоборудованы под их прием ${ }^{14}$. В этой связи любой гражданин в случае отказа приема карты ПС «Мир» в торговой точке может обратиться с жалобой в Роспотребнадзор.

Данные прецеденты подтверждают правильность выбора Банком России в качестве одной из своих стратегических целей увеличение доли безналичных расчетов в общем количестве платежей к 2020 г. Таким образом, несмотря на то, что закон устанавливает обязательность приема карт ПС «Мир» только для торговых точек с годовым оборотом более 40 млн руб., государственным

${ }^{13}$ Годовой отчет Акционерного общества «Национальная система платежных карт» за 2015-2017 гг. [Эл. pecypc]. URL: http://www.nspk.ru/about/investor-relations/disclosure/ annual_reports/ (дата обращения: 28.03.2018).

${ }^{14}$ Принимают карту платежной системы «Мир» [Эл. ресурc]. URL: http://mironline.ru/ service/\#allservice (дата обращения: 10.03.2018). и надзорным органам следует разработать меры стимулирования торговых сетей, годовой оборот которых меньше указанной суммы, к использованию безналичных инструментов в расчетах, например, введя в Налоговый кодекс РФ поправки, предусматривающие налоговые льготы на основании оборотов по карточным транзакциям. Таким образом, речь идет о постепенном переходе от чисто административных методов воздействия на торговые и сервисные точки к экономическим, призванным стимулировать их заинтересованность в приеме карт ПС «Мир».

\section{Таблица 2. Сравнение тарифов платежной системы «Мир} с ведущими МПС 15

\begin{tabular}{|c|c|c|c|}
\hline Тариф & «Мир" & Visa & MasterCard \\
\hline $\begin{array}{l}\text { Вступительный } \\
\text { взнос }\end{array}$ & Отсутствует & $\begin{array}{l}\text { Прямой участник - } \\
\text { до } 335 \text { тыс. долл. } \\
\text { (20,1 млн руб.) }\end{array}$ & $\begin{array}{l}\text { Прямой участник - } \\
\text { от } 30 \text { тыс. до } 150 \text { тыс. } \\
\text { евро (от } 1,95 \text { до } 9,8 \text { млн } \\
\text { руб.) }\end{array}$ \\
\hline $\begin{array}{l}\text { За оборот } \\
\text { по картам, } \\
\text { минимальная } \\
\text { плата }\end{array}$ & Отсутствует & $\begin{array}{l}\text { От } 15 \text { тыс. до } 30 \text { тыс. } \\
\text { долл. (от } 900 \text { тыс. } \\
\text { до } 1,8 \text { млн руб. в квартал) }\end{array}$ & $\begin{array}{l}25 \text { тыс. евро (1,6 млн руб. } \\
\text { в квартал) }\end{array}$ \\
\hline $\begin{array}{l}\text { За оборот } \\
\text { по картам, } \\
\text { от объема } \\
\text { операций }\end{array}$ & $\begin{array}{l}\text { 0,3\%, но не более } 3 \text { руб. } \\
\text { (дебетовая, предопла- } \\
\text { ченная карта), 0,8-2\% } \\
\text { (другие карточные } \\
\text { продукты),только меж- } \\
\text { банковский оборот }\end{array}$ & $\begin{array}{l}0,01-0,05 \%, \text { межбанков- } \\
\text { ский и внутрибанковский } \\
\text { оборот }\end{array}$ & $\begin{array}{l}0,01-0,05 \% \text { межбанков- } \\
\text { ский и внутрибанковский } \\
\text { оборот }\end{array}$ \\
\hline $\begin{array}{l}\text { Первоначаль- } \\
\text { ная настройка }\end{array}$ & $\begin{array}{l}\text { 400-600 тыс. руб. } \\
\text { единовременно } \\
\text { (с 01.02.2017 } \\
\text { по 31.01.2018 тариф } \\
\text { не применялся) }\end{array}$ & $\begin{array}{l}19 \text { тыс. долл. (1,14 млн } \\
\text { руб.) }\end{array}$ & $\begin{array}{l}18 \text { тыс. евро (1,15 млн } \\
\text { руб.) }\end{array}$ \\
\hline $\begin{array}{l}\text { Предоставле- } \\
\text { ние идентифи- } \\
\text { катора (БИН) }\end{array}$ & $\begin{array}{l}10 \text { тыс. руб. едино- } \\
\text { временно }\end{array}$ & $\begin{array}{l}3 \text { тыс. долл. (180 тыс. } \\
\text { руб.) }\end{array}$ & 250 евро (16 тыс. руб.) \\
\hline $\begin{array}{l}\text { Доступ к сети } \\
\text { передачи } \\
\text { данных }\end{array}$ & $\begin{array}{l}50 \text { тыс. руб. ежемесячно } \\
\text { (оплачивает только } \\
\text { прямой или системный } \\
\text { участник) }\end{array}$ & $\begin{array}{l}3 \text { тыс. долл. (180 тыс. } \\
\text { руб.) - прямой участник, } \\
1,5 \text { тыс. долл. (90 тыс. } \\
\text { руб.) - косвенный }\end{array}$ & $\begin{array}{l}\text { от } 2,5 \text { тыс. евро ( } 160 \text { тыс. } \\
\text { руб.) }\end{array}$ \\
\hline
\end{tabular}

${ }^{15}$ Правила и тарифы платежной системы «Мир» [Эл. pecypc]. URL: http://www.nspk.ru/ cards-mir/terms-and-tariffs/ (дата обращения: 05.01.2018); правила и тарифы платежной системы Visa [Эл. pecypc]. URL: https://www.visa.com.ru/visa-everywhere/about-visa/ legislation.html (дата обращения: 05.01.2018); правила и тарифы платежной системы MasterCard [Эл. pecypc]. URL: https://www.mastercard.ru/ru-ru/about-mastercard/whatwe-do/rules-fees.html (дата обращения: 05.01.2018). 
Следующие дополнительные меры могут помочь привлечь большее количество участников в НСПК (держателей карт и кредитных организаций) и повысить интенсивность развития расчетов по платежным картам в российских регионах:

1) предоставление льготных условий при осуществлении платежей в пользу бюджетов всех уровней, муниципальных, федеральных унитарных предприятий и иных государственных организаций с использованием национального платежного инструмента (например, Государственной информационной системы о государственных и муниципальных платежах, при оплате общественного транспорта, услуг ЖКХ и пр.);

2) аккумулирование средств физических лиц, находящихся на картсчетах кредитных организаций, и направление их на реализацию инвестиционных проектов на региональном уровне;

3) активизация финансовых потоков внутри региона посредством продвижения различных социальных программ населению на базе национального платежного инструмента.

\section{Выводы}

В результате проведенного исследования развития национальной системы платежных карт в России можно сделать следующие выводы.

Формирование российской НСПК обусловлено потенциальными рисками, связанными с угрозой потери финансовой безопасности государства, которая проявилась после введения экономических санкций со стороны США. В отличие от международных карточных платежных систем российской НСПК приходится решать задачу не столько по международному масштабированию своего бизнеса, сколько по завоеванию доли на платежном рынке России, на котором господствуют международные платежные системы.

В настоящее время российская НСПК недостаточно развита с точки зрения как количества выпущенных карт, так и интенсивности их использования: на начало 2018 г. доля национального платежного инструмента в общем количестве эмитированных карт составила всего 10,58\%, а за IV квартал 2017 г. доля осуществленных операций составила 7,59\% по сумме и 7,4\%по количеству. Поэтому ПС «Мир» в настоящее время следует рассматривать как специализированную, а не универсальную платежную систему.

На нынешнем этапе развития НСПК уделяет особое внимание реализации многофункциональных платежных, транспортных и социальных проектов в разных российских регионах.

По территории страны использование карт ПС «Мир» распределяется достаточно равномерно с преобладанием в наиболее густо населенных регионах. Потенциальными пользователями национальных карт являются работники бюджетной сферы, а также пенсионеры и студенты, что предполагает наличие определенных рисков, связанных с ограничениями в размерах доходов данных слоев населения и в интенсивности использования данных карт в платежных целях.

При этом государственные меры по поддержке развития ПС «Мир» на законодательном и административном уровне можно признать оправданными лишь на начальном этапе формирования НСПК. Эти меры не должны заменять экономические стимулы по более широкому и интенсивному использованию национальных платежных карт, а также нивелировать рыночную конкуренцию на платежном рынке.

Чтобы стимулировать более интенсивное использование карт ПС «Мир» в безналичных платежах, НСПК необходимо сохранять привлекательные для участников платежной системы тарифы, кредитным организациям - совершенствовать инфраструктуру приема и расчетов по платежным картам и поддерживать развиваемую ПС «Мир» единую программу лояльности. Кроме того, необходимо повышать доверие к финансовым институтам среди населения и уровень их финансовой грамотности. Первые шаги в этом направлении осуществляет Банк России с Министерством образования России, вводя занятия по финансовой грамотности в образовательных учреждениях.

В целом российская НСПК сможет успешно конкурировать с международными системами на национальном платежном рынке лишь в том случае, если будет способна создавать более привлекательные условия для пользователей карт ПС «Мир», внедрять инновации в сфере приема и обработки платежей. Например, возможность совершать бесконтактные платежи с различных мобильных устройств и быстрые трансакции в Интернете с использованием более безопасных и надежных технологий 
хранения данных, а также предлагать ценовые, структурные и функциональные преимущества по своим платежным продуктам для разных участников.

\section{Литература}

Портанский А.П. Антироссийские санкции - меры деструктивные или контрпродуктивные // Деньги и кредит. 2014. № 10. С. 8-10.

Быстров Л. В. Пластиковые карты. М.: Изд. группа «БЦД-Пресс», 2005.

Царенко И. А. Национальная платежная система - риски и перспективы // Банковское дело. 2014. № 11. С. 66-68.

Статья поступила 03.02.2018.

\section{Summary}

Kochergin D. A., Iangirova A.I., St. Petersburg State University

Development of the National Payment Card System in Russia in the Conditions of Economic Sanctions

The article deals with the establishment of the Russian National Payment Card System (NPCS), which is demands special care. The purpose of this article is studying implementation stages of the first independent payment system in Russia. The key indicators of the NPCS contemporary development have been thoroughly investigated. It is concluded that to ensure the fair competition in the market of payment cards it is vital to pay attention on improving the payment infrastructure and implementation the economic insentives for the «Mir» payment system participants. The authors consider that in the long-term period the Russian NPCS would be able to compete with international payment systems in case it got ready to implement innovations and offer price and functional advantages of the pruposed products.

It is expected that the results revealed can be used by economists-researchers, credit institutes and national regulating authorities for improvement of the NSPC development in the conditions of economic sanctions and also for stimulation of cashless payments growth in the country.

Payment system; the National Payment Card System; cashless payment instruments; «Mir» payment card

\section{References}

Portansky A. (2014). Anti-Russian sanctions - destructive or counterproductive sanctions. Money and credit scientific review. No. 10. Pp. 8-10. (In Russ.)

Bystrov L. (2005). Plastic cards. Moscow, Publishing group «BCD-Press». (In Russ.)

Tsarenko I. (2014). National payment system - risks and prospects. Banking. No. 11. Pp. 66-68. (In Russ.) 